\title{
Najstarszy dokument hebrajski na ziemiach polskich (1485) i jego thumaczenia*
}

\begin{abstract}
Zarys treści: Prezentowany artykuł przybliża treść oraz kontekst wystawienia najstarszego zachowanego na ziemiach polskich dokumentu hebrajskojęzycznego, spisanego w gminie krakowskiej w 1485 r. W aneksie zamieszczona została jego edycja wraz z thumaczeniem na język polski oraz jego przekłady na łacinę i niemiecki sporządzone w 1492 r.

Content outline: The present article discusses the content and context of the earliest surviving Polish document written in the Hebrew language, drawn up in the Cracow community in 1485. The appendix brings its edition along with a translation into Polish and two historical translations into Latin and German, produced in 1492.
\end{abstract}

Keywords: Jews, Jewish trade, Cracow, Hebrew document

Słowa kluczowe: Żydzi, handel żydowski, Kraków, dokument hebrajski

1. Jeszcze w początku ubiegłego stulecia autorzy podejmujący pionierskie studia nad najstarszymi dziejami gminy żydowskiej w Krakowie dysponowali źródłami znanymi dziś tylko dzięki zachowanym fotografiom, wykonanym wówczas odpisom lub wzmiankom w literaturze. Wśród tych znajdował się uznawany obecnie za zaginiony „memorbuch”, zachowany wtedy we fragmentach i przechowywany w synagodze Kupa, datowany wówczas na stulecie XIV, ale identyfikowany jako sidur (hebr. sid [d]ur; jid. sider), czyli książeczka zawierająca pełny zbiór modlitw na dni powszednie oraz szabat $^{1}$. Anonimowy glosator przy modlitwie za władcę (,Wszechmocny, który dał

* Szczególne podziękowania należą się Pani Profesor Judith Olszowy-Schlanger z École pratique des hautes études w Paryżu, wybitnej specjalistce w zakresie paleografii hebrajskiej, która zechciała podzielić się swoim doświadczeniem przy przygotowaniu edycji tytułowego dokumentu hebrajskiego.

1 Zob. E. M ü 11 e r, Żydzi w Krakowie w drugiej połowie XIV stulecia, Kraków 1906 (Biblioteka Krakowska 35), cyt. s. 52, il. I-II. H. Z a r e m s k a, Żydzi w średniowiecznej Polsce. Gmina krakowska, Warszawa 2011, s. 26-27, opierając się na opinii Abrahama Dawida z Działu Rękopisów Uniwersytetu Hebrajskiego w Jerozolimie, datowała zarówno tekst modlitwy, jak i kursywną glosę na XV w. W myśl tej interpretacji wymienionego w niej króla Kazimierza należałoby identyfikować z Kazimierzem Jagiellończykiem. Z kolei podczas dyskusji nad prezentowanym tekstem, która odbyła się na posiedzeniu Komisji Historii i Kultury Żydów Polskiej Akademii Umiejętności 14 VI 2017 r., Pan dr hab. Leszek Hońdo z Instytutu Judaistyki Uniwersytetu Jagiellońskiego zauważył, że zabytek ten właściwie należałoby identyfikować jako ,memorbuch”. 
królom i władcom siłę i potęgę do rządów, - - ten niech ześle błogosławieństwo, ochrania i wywyższa tego, którego państwo jest wywyższone") dopisał w nim notę mówiącą, że w kierowanych do Boga prośbach wspominać należy polskiego króla Kazimierza (,a tym jest nasz najmiłościwszy i najłaskawszy król Kazimierz, którego majestat, oby długo był wywyższony") ${ }^{2}$. Znana była także czternastowieczna Biblia, bogato iluminowana, będąca najpewniej dziełem warsztatu ratyzbońskiego. Do Krakowa trafiła zapewne dopiero w XIX w. i początkowo znajdowała się w Starej Synagodze, a następnie w siedzibie Gminy Wyznaniowej Żydowskiej Miasta Krakowa ${ }^{3}$. W końcu XIX w. Feivel Hirsch Wettstein, badacz „starożytności” żydowskich i właściciel antykwariatu przy ul. Szpitalnej w Krakowie, wydał drukiem z jednego z krakowskich pinkasów, czyli prowadzonych $\mathrm{w}$ gminie ksiąg wpisów, notę datowaną na 1494 r. - ,zeznanie długu w wysokości 100 węg. dukatów, bardzo ciekawy układ między szkolnikami krakowskimi”". Recenzujący inną z jego publikacji Izaak Planer dotarł u księgarza Aarona Fausta do złożonego z luźnych arkuszy pinkasu mieszczącego akta z lat 1582-16575. Kiedy zaś Majer Bałaban pisał przed $1912 \mathrm{r}$. monumentalne dzieje Żydów w Krakowie i Kazimierzu, miał jeszcze w rękach statut kahalny z $1595 \mathrm{r}^{6}$, ale $\mathrm{w}$ znanych sobie pinkasach najstarsze zapisy datował dopiero na $1603 \mathrm{r}^{7} \mathrm{~W}$ przypadku epoki średniowiecza, rekonstruowanej w zasadzie tylko i wyłącznie dzięki źródłom chrześcijańskim, znany był Bałabanowi tylko jeden dokument hebrajskojęzyczny spisany w gminie krakowskiej, niedatowany, ale poprawnie łączony z 1485 r., regulujący kwestie żydowskiego handlu detalicznego w Krakowie ${ }^{8}$. Mimo prowadzenia w ostatnich latach zintensyfikowanych prac nad skatalogowaniem i poprawnym rozpoznaniem fragmentów średniowiecznych hebraików zachowanych w oprawach rękopisów krakowskich archiwów i bibliotek, nie udało się dotąd odnaleźć nowych źródeł pisanych do poznania życia gminy krakowskiej i, co ważne, w tej gminie wytworzonych. Tytułem przykładu warto natomiast

${ }^{2}$ E. M ü 11 e r, Żydzi, s. 52.

3 Z. A m e i s e n o w a, Biblia hebrajska XIV-go wieku w Krakowie i jej dekoracja malarska, Kraków 1929, s. 16-19.

4 Zob. M. B a ł a b a n, Przegląd literatury historii Żydów w Polsce, Kwartalnik Historyczny 17, 1903, s. 477 (tam omówienie wydawnictwa Wettsteina, Devarim 'atikim: mi-pinkese ha-kahal be-Kraka le-korot Yiśra'el va-hakhamav, rabanav u-manhigav be-Polanya bi-khelal uve-Kraka bi-ferat / Materialen zur Geschichte der Juden in Polen, insbesondere in Krakau, Kraka 1892).

5 I. P l a n e r, rec.: Feivel Hirsch Wettstein, Kadmoniyot mi-pinkesa'ot Yeshanim: le-korot Yiśra'el be-Folin bi-khelal uvi-Kraka bi-ferat / Quellenschriften zur Geschichte der Juden in Polen, insbesondere in Kraków [1900], Kwartalnik Historyczny 8, 1894, s. 127, przyp. 1.

6 M. B a ła b a n, Die Krakauer Judengemeinde-Ordnung von 1595 und ihre Nachträge, Jahrbuch der Jüdisch-Literarischen Gesellschaft 2, 1912 (5673), s. 299-308, gdzie szczegółowy opis kodeksu; tłumaczenie polskie: Statut krakowskiej gminy żydowskiej z roku 1595 i jego uzupełnienia. Tłumaczenie sporządzone na podstawie odpisu Majera Bałabana, oprac. A. Jakimyszyn, Kraków 2005.

7 M. B a ła b a n, Historia Żydów w Krakowie i na Kazimierzu 1304-1868, t. I, wyd. 2, Kraków 1931, s. 561. Wyczerpującą biografię tego autora opracował I. M. B i d e r m a n, Mayer Balaban. Historian of Polish Jewry. His Influence on the Younger Generation of Jewish Historians, New York 1976, zwł. s. 129-136 (o monografii gminy krakowskiej).

${ }^{8}$ M. B ałaban, Historia, t. I, s. 60, przyp. 6; fot. po s. 114. 
odnotować, że w zbiorach Biblioteki Jagiellońskiej w ramach projektu „Books within Books. Hebrew Fragments in European Libraries”, kierowanego przez Judith Olszowy-Schlanger, zidentyfikowano dotąd 109 kodeksów mieszczących fragmenty rękopisów hebrajskich, przede wszystkim liturgicznych oraz prawniczych, w tym rzadkie w skali europejskiej czternastowieczne fragmenty księgi rachunkowej prowansalskiego lichwiarza ${ }^{9}$. Z kolei w zbiorach Archiwum Narodowego rozpoznano jak dotąd fragment Biblii hebrajskiej (Księga Ezechiela), użyty przed końcem XV w. jako oprawa rękopisu mieszczącego m.in. kalendarz domu altarystów kościoła Mariackiego w Krakowie ${ }^{10}$.

Wymieniony w tytule niniejszego artykułu dokument z 1485 r. był już wprawdzie, jak wspomniano, znany badaczom historii gminy krakowskiej, jednakże nie doczekał się jak dotąd ani kompletnego omówienia, ani tym bardziej nowoczesnej edycji. W dotychczasowej literaturze pomijano także informację, że od czasu średniowiecza przechowywany był on w specjalnie w tym celu przygotowanej pergaminowej kopercie wraz z trzema innymi dyplomami, początkowo tylko z dokumentem wojewody krakowskiego Jana Amora z Tarnowa z 14 VI 1485 r., następnie zaś (od 1492 r.) także z dwoma nieuwierzytelnionymi tłumaczeniami tekstu hebrajskiego na łacinę i niemiecki ${ }^{11}$. Przy analizie tego dokumentu nie można więc nie uwzględnić kontekstu kancelaryjnego.

Dwa ze wspomnianych wyżej dokumentów (łacińskie tłumaczenie dyplomu hebrajskiego datowane ogólnie na czerwiec 1485 r. oraz dokument Jana Amora z Tarnowa) do obiegu naukowego wprowadził Franciszek Piekosiński, publikując ich teksty w 1879 r. ${ }^{12}$ Należy przy tym zaznaczyć, że ten znakomity wydawca źródeł nie sięgnął do oryginałów, bezspornie znajdujących się wówczas w Archiwum Aktów Dawnych Miasta Krakowa. Wykorzystał natomiast ich późne, siedemnastowieczne kopie,

9 J. O 1 s z o w y - S c h 1 a n g e r, Fragmenty rękopisów hebrajskich w Bibliotece Jagiellońskiej i ich znaczenie, w: Studia żydowskie w Polsce - przeszłość, stan obecny, perspektywy. Studium selektywne, Kraków 2014 (Prace Komisji Historii i Kultury Żydów PAU 6), s. 156158; t a ż, Binding Accounts. A Leger of a Jewish Pawn Broker from 14th Century Southern France (MS Kraków, BJ Przyb/163/92), w: Books within Books. New Discoveries in Old Book Bindings, Leiden-Boston 2014, s. 97-147 (wraz z edycją).

10 Archiwum Narodowe w Krakowie (dalej cyt.: ANK), rkps nr 3361. Oprawę tego rękopisu reprodukuje ostatnio H. Z a r e m s k a, Żydzi, s. 58, il. 5. Pod ilustracją umieszczono jednak błędny podpis, że karty z tekstem hebrajskim pochodzą z machzoru (modlitewnika) będącego importem z ziem niemieckich z XIII-XIV w. W innym zaś miejscu (s. 27) autorka podała, że są to fragmenty „modlitwy żałobnej, wklejone w oprawę powstałego około 1437 roku rękopisu zawierającego teksty związane z domem altarystów kościoła Najświętszej Marii Panny w Krakowie". Informacje te powtórzono również w wydaniu niemieckojęzycznym: H. Z a r e m s k a, Juden in mittelalaterlichen Polen und die Krakauer Judengemeinde, Osnabrück 2013 (Klio in Polen 17). Zidentyfikowany tekst to fragmenty Księgi Ezechiela: okładzina górna, kolumna prawa Ez 27, 19-21, środkowa Ez 29, 27-30, lewa Ez 28, 2; okładzina tylna, kolumna prawa oraz tekst w górnej części karty nieczytelne, kolumna środkowa Ez 27, 22-25, kolumna lewa Ex 27, 30-33, zob. M. S t a r z y ń s k i, Opis rękopisu nr 3361, w: Kalendarz domu altarystów kościoła Mariackiego w Krakowie, wyd. B. Wyrozumska (w druku).

11 ANK, sygn. 658/1248-1251.

12 Kodeks dyplomatyczny miasta Krakowa, wyd. F. Piekosiński, t. I, Kraków 1879, nr 192-193. 
zachowane w tzw. Kodeksie Zaleskiego ${ }^{13}$. Około 1901 r. do oryginału hebrajskiego, najprawdopodobniej jako pierwszy, dotarł Feivel Hirsch Wettstein, który opublikował zarówno tekst hebrajski, jak i tłumaczenie na język niemiecki, nie podając przy tym adresów bibliograficznych ${ }^{14}$. Trudno także szukać wzmianek o nich w drukowanym katalogu dokumentów archiwum krakowskiego z 1907 r., w którym pomieszczono tylko opisy dyplomów pergaminowych ${ }^{15}$. Z edycji Piekosińskiego korzystał Eugeniusz Müller, ale w szczegółach interpretował ją nie do końca poprawnie ${ }^{16}$. Do oryginału hebrajskiego dotarł także Majer Bałaban, publikując w 1912 r. po raz pierwszy jego fotografię $e^{17}$. Dyplom ten znał także Ignacy Schipper ${ }^{18}$. W nowszej literaturze jego treść dokładniej omawiały Bożena Wyrozumska ${ }^{19}$ oraz Hanna Zaremska ${ }^{20}$. Z kolei przywoływana już J. Olszowy-Schlanger uznała go przed kilkoma laty za zaginiony ${ }^{21}$. Jako że oryginały wszystkich czterech dokumentów wraz z pergaminową kopertą zachowały się do dziś w zbiorach Archiwum Narodowego w Krakowie, konieczne stało się przygotowanie ich wspólnej edycji krytycznej, opartej po raz pierwszy na autopsji oryginałów i zaopatrzonej w stosowny komentarz, stanowiący w pewnym sensie podsumowanie dotychczasowych badań nad tym wyjątkowym zabytkiem piśmiennictwa.

Tytułowy dyplom, jak już wyżej zasygnalizowano, dotyczy żydowskiego handlu detalicznego w Krakowie. Otóż latem 1485 r. krakowscy Żydzi, być może w jakiś sposób „zaszantażowani” przez władze miejskie, wyrazili zgodę na wydatne ograniczenie swojego udziału w handlu detalicznym w mieście. Zapewne też na prośbę rady pisarz gminy sporządził wtedy osobny dokument, który następnie „na dowód i świadectwo" złożono w ratuszu. Spisano go na niewielkiej kartce papieru (szerokość 218, wysokość $162 \mathrm{~mm}$ ) kaligraficznym duktem aszkenazyjskim, charakterystycznym dla stulecia $\mathrm{XV}$, świadczącym zresztą o wysokiej randze tego pisma. Ówcześni starsi gminy: Mojżesz syn Efraima (Fiszla), jego brat Józef, Jakub syn Aleksandra oraz Mordechaj syn Jakuba, w imieniu całego kahału stwierdzali, że odtąd Żydzi krakowscy nie będą uczestniczyli w handlu detalicznym (z chrześcijanami). Wyjątek czyniono jedynie dla posiadaczy zastawów niewykupionych w terminie

13 ANK, rkps nr 1449 (Codex iurium et privilegiorum urbis metropolis Cracoviensis z 1694 r.).

14 F. H. We t t s te i n, Mi-pinkase ha-kahal be-Kraka: le-korot Yiśra'el va-hakhamav, rabanav u-manhigav be-Polania bi-khelal uve-Kraka bi-ferat, Bresloia [1901], s. I-II; data tej publikacji za: M. B a ła b a n, Felwel Hirsz Wetstein, Nowe Życie 1, 1924, s. 435-437.

15 Katalog Archiwum Aktów Dawnych Miasta Krakowa, cz. 1: Dyplomy pergaminowe, Kraków 1907.

16 E. Mü 11 e r, Żydzi, s. 19-20.

17 M. B a ła b a n, Historia, t. 1, s. 59-61, il. po s. 114.

18 I. S c h i p p e r, Studia nad stosunkami gospodarczymi Żydów w Polsce podczas średniowiecza, Lwów 1911 (Monografie z Historii Żydów w Polsce 4), s. 192-193.

19 B. W y r o z u m s k a, Czy Jan Olbracht wygnał Żydów z Krakowa?, Rocznik Krakowski 59, 1993, s. 7 (pierwodruk: Did King Jan Olbracht Banish the Jews from Cracow?, w: The Jews in Poland, t. I, Cracow 1992, s. 27-37).

20 H. Z a r e m s k a, Żydzi, s. 208-209, 214.

21 J. O ls z ow y - S c hl a n g e r, Fragmenty, s. 155. Autorka ta pisała nadto, że „znane dotychczas hebrajskie dokumenty dotyczące średniowiecznego Krakowa są nieliczne” (tamże, s. 154). Precyzując tę wypowiedź, należy wskazać, że jest to jeden dokument. 
(tzw. zastaw pod przepadkiem - obligatio sub lapsu), które będą oni mogli wystawiać na sprzedaż, ale tylko we własnych domach, publicznie natomiast jedynie we wtorki i piątki (czyli dni targowe) oraz w czasie jarmarku odbywającego się w Krakowie, jak wiadomo, trzykrotnie, na Znalezienie Krzyża Świętego w maju, na św. Barnabę w czerwcu oraz na św. Michała we wrześniu ${ }^{22}$. Warunkiem sine qua non skorzystania z tej klauzuli było złożenie przysięgi, a więc użycie jednego z dwóch głównych środków dowodowych w prawie żydowskim, że dany przedmiot przepadł w zastawie. Gdyby natomiast doszło do tego, że Żyd zostanie zatrzymany na sprzedaży rzeczy poza ustalonymi wyżej terminami, wówczas towar miał podlegać konfiskacie, handlującemu groziło zaś zamknięcie w więzieniu ratuszowym do czasu uiszczenia kary w wysokości 3 grzywien, płaconej na rzecz wojewody ${ }^{23}$. Ubogim Żydówkom zezwalano natomiast sprzedawać wytwarzane przez nie czepce oraz ozdoby zakładane na szyję. Ta dość drastyczna w wymowie umowa, opatrzona własnoręcznymi podpisami czterech wymienionych starszych, została złożona, jak już wspomniano, w ratuszu krakowskim i niewątpliwe, przede wszystkim z uwagi na barierę językową, musiała być traktowana jako pewien przedmiot o znaczeniu magicznym - posiadający rzec jasna moc prawną, ale faktycznie niezrozumiały dla chrześcijańskich odbiorców ${ }^{24}$.

2. Przyczyny wystawienia tytułowego dokumentu z 1485 r. pozostają i chyba pozostaną niewyjaśnione. Można jednak podjąć próbę osadzenia tego dyplomu w kontekście historycznym - na tle działań prowadzonych wówczas przez koronne mieszczaństwo związane z kilkoma ważniejszymi ośrodkami handlowymi, zmierzających do ograniczenia uprawnień kupców gości. Do kategorii tej zamierzano bowiem włączyć także kupców żydowskich.

W zachowanym materiale źródłowym z tego czasu (w tym przypadku są to przede wszystkim miejskie księgi sądowe) trudno doszukiwać się śladów szczególnych napięć między władzami miasta, miejscowym kupiectwem a społecznością żydowską. W styczniu 1469 r. przełożeni gminy (seniores Judei): Mojżesz, Jakub, Nacham, Abraham z Sącza i Jakub Nol, wraz z Janem Chamcem z Dobranowic sędzią żydowskim oraz innym Janem notariuszem i podsędkiem zawarli ugodę z braćmi Długoszami, Janem starszym (kronikarzem) i Janem młodszym, kanonikami krakowskimi, w myśl której zrzekli się terenu posiadanego przez gminę przy ul. Żydowskiej, gdzie znajdowały się dwie synagogi, stara i nowa, szpitale oraz cmentarze (za Kolegium Artystów i w pobliżu domu kasztelana krakowskiego Jana z Tęczyna), w zamian uzyskując teren przy ul. Szpiglarskiej za kościołem św. Szczepana, gdzie stała już synagoga; grunt ten został wyceniony na 200 kóp szerokich groszy praskich. Dodać należy,

22 J. W y r o z u m s k i, Kraków do schyłku wieków średnich, Kraków 1992 (Dzieje Krakowa, t. I), s. 390.

${ }^{23}$ Karę w tej samej wysokości odnotowano już w przywileju żydowskim Kazimierza Jagiellończyka z 1453 r., odwołanym następnie na sejmie nieszawskim, w paragrafie regulującym kwestię nieposłuszeństwa wobec przełożonych, zob. Najdawniejszy układ systematycznego prawa polskiego z XV wieku, wyd. B. Ulanowski, Kraków 1897 (Archiwum Komisji Prawniczej 5), s. 102, art. XI: De pene rebellionis Judeorum; H. Z a r e m s k a, Żydzi, s. 372-373.

${ }^{24}$ Zob. T. J u re k, Stanowisko dokumentu w średniowiecznej Polsce, Studia Źródłoznawcze 40, 2002, s. 13-14. 
czego niestety nie dostrzegano w dotychczasowej literaturze, iż treść tego dyplomu została de verbo ad verbum odpisana de libro iuris Judaici, a zatem z prowadzonego wówczas $\mathrm{w}$ gminie pinkasu ${ }^{25}$. M. Bałaban w sposób dość emocjonalny pisał, że „przeniesienie się Żydów na ulicę Szpiglarską (pl. Szczepański) równało się prawie wygnaniu"26. Obecnie wiadomo, że była to akcja w zasadzie zaplanowana, już bowiem w 1. 1467-1468 nastąpiły liczne zmiany własności nieruchomości, zarówno przy ul. Garncarskiej (obecna Gołębia), gdzie Żydzi zbywali posiadane dotychczas budynki, jak i przy ul. Szpiglarskiej, gdzie stawali się nowymi posesjonatami. Na uwagę zasługuje z pewnością kupno domu przy Szpiglarskiej w kwietniu $1468 \mathrm{r}$. przez Michila Barocha, który dokonał tego imieniem ganczen gemeynne der Juden, zobowiązując się jednocześnie, że bez jej zgody nie sprzeda go miastu ${ }^{27}$. „Czy ten dom miał służyć żydowskim celom publicznym, lub jakie były inne racje tego szczególnego zastrzeżenia, nie wiadomo"28. W sferze hipotez muszą natomiast pozostać dawniejsze domniemania, czy owe przenosiny z 1469 r. miały jakikolwiek związek z pewnego rodzaju „szantażem” ze strony władz miasta i w efekcie stanowiły ustępstwo gminy wobec wprowadzenia ewentualnych ograniczeń w handlu żydowskim $^{29}$. Na pewno w 1477 r. doszło w Krakowie do pewnych incydentów (kradzieży majątków żydowskich) w związku z pożarem, ale chyba nie miały one większego zasięgu $^{30}$. Wydaje się natomiast, że brak zachowanych akt ławniczych, w których notowano obrót nieruchomościami, z ostatniego ćwierćwiecza XV w. w sposób istotny zaciemnia relacje chrześcijańsko-żydowskie w Krakowie około 1485 r. ${ }^{31}$ Natomiast nie jest wykluczone, że zanim doszło do rozmów starszych kahału krakowskiego $\mathrm{z}$ radą miejską, w ratuszu dysponowano już informacjami o dwóch interesujących przywilejach związanych ze statusem tzw. kupców obcych. W marcu 1483 r. książę mazowiecki Bolesław V na prośbę władz Starego Miasta Warszawy, które wyłożyły w tym celu dość znaczną kwotę 120 florenów węgierskich, wystawił dokument, mocą którego, oprócz m.in. zgody na wyszynk piwa wareckiego w piwnicy ratuszowej, w wydatny sposób ograniczył prawa kupców gości. Nie mogli oni odtąd prowadzić handlu detalicznego (tales nonnisi integre in stucis, staminibus, lapidibus res suas quascunque et merces vendendi habeant facultatem ${ }^{32}$. Mimo że Żydzi

${ }^{25}$ Codex diplomaticus Universitatis Studii Generalis Cracoviensis, t. II, Cracoviae 1873, nr 223; B. Wyrozumska, J. Wy ro z u m s ki, Nowe materiały do dziejów Żydów krakowskich w średniowieczu, przedruk w: J. Wyrozumski, Cracovia mediaevalis, Kraków 2010, s. 302; pierwodruk w języku angielskim: Kroke - Kazimierz - Cracow. Studies in the History of Cracow Jewry, Tel Aviv 2001, s. 29-42; po polsku: Studia Judaica 6, 2003, s. 1-18.

${ }^{26}$ M. B a ł a b a n, Historia, t. 1, s. 58.

27 Żydzi w średniowiecznym Krakowie. Wypisy źródłowe z ksiąg miejskich krakowskich / The Jews in Mediaeval Cracow. Selected Records from Cracow Municipal Books, wyd. B. Wyrozumska, Kraków 1995, nr 512; H. Z a r e m s k a, Żydzi, s. 359-361, 364-365; D. N i e m i e c, Siedziby żydowskie w średniowiecznym Krakowie, w: Cracovia Judaeorum 3D. Katalog wystawy, Kraków 2013, s. 50-52.

28 B. Wy rozum s ka, J. Wy ro z u m s k i, Nowe materiały, s. 302.

29 H. Z a r e m s k a, Żydzi, s. 360.

30 Żydzi, nr 572: pro infamia furti ex Judeis tempore ignis viventis.

31 B. W y r o z u m s k a, Kancelaria miasta Krakowa w średniowieczu, Kraków 1995, s. 69.

32 Przywileje królewskiego miasta stołecznego Starej Warszawy 1376-1772, wyd. T. Wierzbowski, Warszawa 1913, nr 21; H. Z a r e m s k a, Żydzi, s. 209-210. 
w tym dyplomie nie zostali wymienieni, „z pewnością niektóre z jego postanowień ich dotyczyły" ${ }^{\prime 3}$. Istotny w omawianym kontekście, jeśli nawet nie ważniejszy, jest dokument króla Kazimierza Jagiellończyka wydany na sejmie lubelskim w lutym 1484 r. (obserwowanym zapewne przez przedstawicieli Krakowa), dotyczący kupców ormiańskich i żydowskich. Król w odpowiedzi na skargę wniesioną przez mieszczan Lwowa zwracał się do urzędników Rusi i Podola, by czuwali nad respektowaniem składu lwowskiego w szczególności przez Żydów i Ormian, którzy wystawiali na sprzedaż towary w mniejszych ośrodkach. W przypadku złapania na takim procederze, przedmioty handlu miały podlegać konfiskacie na rzecz skarbu królewskiego ${ }^{34}$.

Do siedziby władz Krakowa tytułowy dokument hebrajski trafił najpewniej równolegle z dokumentem wojewody z 14 VI 1485 r., sprawującego zwierzchność nad ludnością żydowską, potwierdzającym owe regulacje, ale nie wraz z thumaczeniem na język łaciński, jak przypuszczał M. Bałaban ${ }^{35}$. Uprawnione jest także przypuszczenie, że drugi egzemplarz dyplomu wojewodzińskiego złożono w archiwum kahalnym. Wejście w życie jego postanowień najpewniej jednak nie nastąpiło ${ }^{36}$. Wydaje się, że samo wystawienie osobnego dyplomu hebrajskiego oraz potwierdzenia jego tenoru przez wojewodę wiązało się raczej z manifestacją przewagi władz miasta niż z faktycznym zaprowadzeniem obostrzeń, które w rzeczywistości rugowałyby Żydów z jakiegokolwiek udziału w życiu ekonomicznym miasta. Wpisywało się także w czytelny sposób zarówno w ówczesną politykę władz Krakowa, czy też, spoglądając na problem nieco szerzej, w obserwowane w końcu XV w. dążenia polskiego mieszczaństwa głównych ośrodków handlowych do stopniowego ograniczania prerogatyw tak zwanych hospites. Procesu tego nie należy oczywiście rozpatrywać jako skoordynowanej w jakikolwiek sposób akcji, lecz tylko ciąg partykularnych w swej istocie działań władz dbających o interesy konkretnej gminy. W literaturze przedmiotu nie zauważono jak dotąd, że już tydzień po wystawieniu dokumentu wojewody krakowskiego Kazimierz Jagiellończyk potwierdził miastu Krakowowi dawniejsze przywileje związane z poborem cła kwartnikowego, pobieranego od każdego postawu sukna wwożonego do miasta przez kupca nieposiadającego miejscowego obywatelstwa ${ }^{37}$. Tego samego dnia monarcha nakazał również, by kupcy wrocławscy udający się na Ruś nie omijali składu krakowskiego ${ }^{38}$. Wystawienie tych dyplomów nie nastąpiło oczywiście z inicjatywy panującego. Było natomiast efektem zabiegów, często nieformalnych, władz miejskich ${ }^{39}$. W przedstawionym kontekście trudno także nie wspomnieć o wyroku wydanym przez Jana Olbrachta, pełniącego od 1486 r. funkcję królewskiego namiestnika na Rusi, w sporze między chrześcijańskimi kupcami lwowskimi a kupcami żydowskimi, którego przedmiotem była

${ }_{33}$ H. Z a r e m s k a, Żydzi, s. 209.

34 Akta grodzkie i ziemskie z czasów Rzeczypospolitej Polskiej z Archiwum tak zwanego bernardyńskiego we Lwowie, t. VII, Lwów 1878, nr 74; H. Z a r e m s k a, Żydzi, s. 210.

${ }_{35}$ M. B a $\nmid$ a b a n, Historia, t. 1, s. 60.

36 Tak jako pierwszy wnioskował I. S c h i p p e r, Studia, s. 194.

37 Kodeks dyplomatyczny miasta Krakowa, t. I, nr 194.

38 Tamże, nr 195.

39 Por. M. Star zyńs ki, Krakowska rada miejska w średniowieczu, Kraków 2010 (Maiestas, Potestas, Communitas 3), s. 163-166. 
detaliczna sprzedaż sukna. Władze Lwowa stały na stanowisku, że kupcy żydowscy we Lwowie podlegają takim samym obostrzeniom, jak w innych ośrodkach miejskich Królestwa Polskiego: Krakowie, Poznaniu i Sandomierzu, gdzie handel detaliczny był im zabroniony. Dokumenty tej treści dla Poznania i Sandomierza nie są obecnie znane. W przypadku Krakowa wolno natomiast domyślać się, że lwowianie dysponowali wówczas wiedzą o dyplomie Jana Amora z Tarnowa. Królewicz Olbracht uznał rację władz Lwowa ${ }^{40}$. H. Zaremska słusznie zatem wskazywała, że niektóre z przywoływanych wyżej dokumentów przez swoje postanowienia prowadzily do umieszczenia Żydów w dość pojemnej przecież kategorii hospites, ,niepodlegających prawu i jurysdykcji miejskiej i nieograniczonych zasadami handlowania w mieście", ergo zmiany ich statusu społecznego ${ }^{41}$.

M. Bałaban, prowadząc swoją narrację w sposób dość subiektywny, uważał, że „starszyzna żydowska poszła na ratusz, by tutaj publicznie zrzec się praw ludzkich, tj. prawa uczciwego zarobkowania na życie" ${ }^{42}$. Według tego badacza omijanie omawianego rozporządzenia z 1485 r. przez Żydów miało być przyczyną licznych konfiskat towarów, a w efekcie wywołać nawet rozruchy. Wtedy także, w 1492 r., w ratuszu miano zlecić przetłumaczenie dyplomu hebrajskiego na język niemiecki celem obwołania po mieście, „by każdy kupiec i rzemieślnik je poznał”43. Wnioski te nie mają jednak żadnego oparcia w materiale źródłowym. W kancelarii krakowskiej rzeczywiście sporządzono w 1492 r. thumaczenia dyplomu hebrajskiego na łacinę i niemiecki, ale jako nieuwierzytelnione służyły najpewniej jedynie do użytku wewnętrznego. Być może miało to związek ze zmianą na tronie, na pewno zaś z kwestią znajomości obu języków wśród władz miasta. Kilka lat później notariusz Jan Heydeke w przedmowie do zestawienia stałych dochodów gminy, zredagowanej w języku łacińskim, pisał, że główny tekst owej pomocy kancelaryjnej podaje w języku niemieckim po to, aby każdy z grona rajców mógł go zrozumiećt4.

Tłumaczenia tytułowego dokumentu, sporządzone przez osobę (osoby?) biegle władającą (władające) hebrajskim (anonimowego konwertytę?), różnią się nieznacznie względem formy wynikającej ze stosowanej praktyki kancelaryjnej. Natomiast porównując ich treść, uwagę należy zwrócić na kilka terminów występujących w oryginale hebrajskim, a następnie oddanych w przekładach. Zestawienie to wypada rozpocząć od określenia „przełożonych” (raszim), ,świętej gminy” (kehilah kedoshah), odnośnie do których w obu tłumaczeniach posłużono się synonimicznym odpowiednikiem „starszych” (seniores/eldsten). W źródłach łacińskojęzycznych z terenu ziem polskich znane jest ono co prawda już od XIII w. ${ }^{45}$, aczkolwiek w kręgu miasta rządzącego się prawem niemieckim odnoszone jest bądź do rajców starych (czyli tych, którzy

${ }^{40}$ Akta grodzkie i ziemskie, t. VII, nr 89; H. Z a r e m s k a, Żydzi, s. 211.

${ }^{41}$ H. Z a r e m s k a, Żydzi, s. 211-212.

${ }^{42}$ M. B a $\nmid$ a b a n, Historia, t. I, s. 61.

43 Tamże, s. 61-62.

44 Jan Heydeke, Census civitatis conscripti. Spis dochodów miasta Krakowa z 1500 roku ze zbiorów Archiwum Państwowego w Krakowie, wyd. M. Starzyński, Kraków 2009 (Cracovienses fontes minores 2), s. 3-4.

45 Kodeks dyplomatyczny Wielkopolski, t. 1, [wyd. I. Zakrzewski], Poznań 1877, nr 574 (Judeis senioribus Kalissiensibus); H. Z a re m s k a, Żydzi, s. 372. 
nie zasiadali $\mathrm{w}$ urzędujących $\mathrm{w}$ danym roku władzach, ale stale mających wpływ na prowadzoną przez gminę politykę), bądź do starszych cechowych. Zgoda na przyjęcie omówionych wyżej postanowień zapadła w gronie „wszystkich mężów kahału". Termin ten (kahal) oznaczać może zarówno zarząd gminy (najczęściej czternastoosobowy), jak i całą jej społeczność. Jego właściwe zrozumienie ułatwiają tłumaczenia, w których został zastąpiony pojęciem communitas/gemene oznaczającym wszystkich obywateli gminy.

Interesująca z punktu widzenia dyplomatycznego jest także formuła mówiąca o zapieczętowaniu tego dyplomu podpisami, a zatem nadaniu mu znamion wierzytelności (cum sigillo manus nostre proprie / mit zigel unserer hantschrifft), nieznana w zasadzie dyplomatyce chrześcijańskiej tego czasu, w której nadanie mocy prawnej dokumentowi łączyło się w pierwszej kolejności z zaopatrzeniem go w pieczęćc ${ }^{46}$.

Jeśli chodzi o różnice między tekstem hebrajskim a jego przekładami, wskazać należy przynajmniej trzy miejsca. Po pierwsze, potencjalnych klientów kupców żydowskich w obu tłumaczeniach określono jako chrześcijan (christianis), podczas gdy w oryginale nazwano ich gojami, a więc nie-Żydami. Po drugie, nie ma zbieżności między tekstem hebrajskim a przekładami względem geografii handlu. W pierwszym z nich wymienione zostały tylko place w mieście (beszukim), w dwóch pozostałych zapis ten poszerzono o miejsca circa civitatem. Po trzecie, uwagę trzeba zwrócić na kwestię przysięgi składanej przez Żydów odnośnie do zastawów będących przedmiotami handlu. W wersjach łacińskiej i niemieckiej podano jedynie, że jest to przysięga na Dziesięć Przykazań (ad Decem Precepta / uff dy Czechen Gebot). W tekście hebrajskim mowa jest natomiast wyraźnie o przysiędze Tory na Dziesięć Przykazań. Składano ją w synagodze, a informację o złożeniu przynosił przed sąd chrześcijański miejscowy szkolnik. Osoba przysięgająca miała nosić na ramionach tałes (indutus clamide), na głowie zaś czapkę (pileum Judaicum), ale nie w znaczeniu signum infamiae. Nadto w momencie składania iuramentum winna być zwrócona twarzą ku wschodowi i stać bosymi stopami na stołku (verti contra solem seorsum et stare nudipes supra unam sedem ${ }^{47}$. Dodać należy, że przysięgano na rodał, czyli wyjęty z aron ha-kodesz zwój Tory przykrywany czarną tkaniną. Nierzadko przysięga ta $\mathrm{w}$ swej warstwie ceremonialnej mieściła elementy hańbiące, ale przekazy o tym nie przechowały się w źródłach polskich ${ }^{48}$.

Na osobną uwagę zasługują wreszcie nazwy części garderoby wytwarzane przez ubogie Żydówki: micnefat i anakim, które w thumaczeniach oddano jako pepla et

${ }^{46}$ H. Z a re m s k a, Żydzi, s. 377, dowodziła natomiast, że „,brak w wersji hebrajskiej wzmianki o umocnieniu dokumentu pieczęcią wynika z faktu, że pieczęć została dołączona do aktu". Być może wniosek ten opiera się na nie do końca poprawnym tłumaczeniu tekstu łacińskiego (testificamus cum sigillo manus nostre proprie) „poświadczamy pieczęcią, własnoręcznie" (tamże, s. 376).

47 Najdawniejszy układ, s. 111.

${ }^{48}$ H. Z a r e m s k a, Iuramentum Iudeorum - żydowska przysięga w średniowiecznej Polsce, w: E scientia et amicitia. Studia poświęcone Profesorowi Edwardowi Potkowskiemu w sześćdziesięciopięciolecie urodzin i czterdziestolecie pracy naukowej, Warszawa-Pułtusk 1999, s. 229-243, zwł. 237-240; także H. H. C o h n, Juramentum Judaeorum, more Judaico (The Jewry Oath), w: Encyclopedia Judaica, wyd. 2, Detroit 2007, s. 362; I. L e v it a t s, Oath more Judaico, w: tamże, s. 364-365. 
colliria / habwe und colner, a zatem czepce i naszyjniki lub kołnierze. Odrzucić należałoby łączenie tych elementów stroju z tymi charakterystycznymi dla ubioru kobiet wyznania mojżeszowego, a więc bindą (jid.: szternticht), czyli zakładaną na przód głowy, a nakładaną na czepce przez mężatki tkaną przepaską, zdobioną szlachetnymi kamieniami (znaną na pewno w końcu XVI w.) oraz napierśnikiem, czyli wiązanym na szyi pasem aksamitnej tkaniny ${ }^{49}$. Nabywcami tych wyrobów musiałby być bowiem przede wszystkim chrześcijanki.

3. W 1494 r. władze kahalne oraz jakaś część mieszkańców gminy przeniosły się z Krakowa do Kazimierza, co w tamtejszych źródłach miejskich określono charakterystycznym dla kancelarii miejskiej mianem locacio, oznaczającym nie tylko założenie nowej gminy, ale także przeniesienie już istniejącej w nowe miejsce ${ }^{50}$. $Z$ pejzażu Krakowa Żydzi jednak nie zniknęli, nadal wynajmując sklepy i prowadząc własne interesy. Dokument z 1485 r. ani jego potwierdzenie przez wojewodę Jana Amora Tarnowskiego, przechowywane w pergaminowej kopercie w archiwum ratuszowym, nie były jednak, jak się wydaje, uznawane za szczególnie istotne, skoro nie umieszczono ich w przygotowywanym na początku XVI w. nowym kopiariuszu miejskim, znanym jako Kodeks Behema. Do ich postanowień czasem jednak odwoływano się, jak chociażby w przywileju Zygmunta I z 7 VI 1533 r. regulującym m.in. kwestie dotyczące handlu prowadzonego przez Żydów krakowskich bądź mieszkających w Kazimierzu, kiedy za obowiązujące uznano postanowienia dyplomu wojewody Jana Amora ${ }^{51}$. U schyłku XVII w. wciągnięto te teksty natomiast do zbioru przywilejów miejskich opracowanego przez Jana Zygmunta Zaleskiego ${ }^{52}$. Jeszcze w 1797 r., w nowej rzeczywistości politycznej, nowe władze Krakowa przedłożyły do zatwierdzenia dokument wojewody w Gubernium Krajowym dla Galicji Zachodniej ${ }^{53}$. Wydaje się jednak, że jego postanowienia pozostawały wówczas już tylko wspomnieniem dawno minionej rzeczywistości, nie zaś realnym narzędziem w sporach miasta z ludnością żydowską. Trzysta lat wcześniej doskonale wpisywały się natomiast w politykę władz niektórych ośrodków miejskich, które broniąc interesów własnych kupców, zmierzały do odsunięcia od handlu detalicznego kupców żydowskich przez zaliczenie ich do grupy kupców obcych (gości). Dotychczasowi

49 Por. I. T u r n a u, Ubiór żydowski w Polsce XVI-XVIII wieku, Przegląd Orientalistyczny 1987, z. 3, s. 297-311.

${ }_{50}$ M. S t a r z y ń s k i, Średniowieczny Kazimierz, jego ustrój i kancelaria, Kraków 2015, s. 93-97 (tam omówiona starsza literatura).

${ }^{51} \mathrm{Z}$ treści tego dyplomu wynika jakoby chronologicznie starszy był dokument wojewodziński, który przyjęty przez starszych kahalnych został następnie własnoręcznie przez nich podpisany: iuxta ordinacionem et constitucionem magnifici olim Joannis Amor de Tharnow palatini Cracouiensis, quam ipsi illo tempore suapte sponte susceperant, et cui seniores illorum, qui protunc fuerant, se characteribus Judaicis subscripserant, zob. Prawa, przywileje i statuta miasta Krakowa (1507-1795), t. I, z. 1, wyd. F. Piekosiński, Kraków 1885, s. 52, § 3.

52 ANK, rkps nr 1449, k. 56v-57r.

53 Compendium iurium caesare-regiae urbis metropolis Cracoviae, quorum in sequelam Judaei mercaturae ac opificorum exercitio ceterisque facultatibus civicis hac in urbe eiusque in circumferentiis gaudere prohibentur, [Kraków 1797], k. A-Av; M. B ała b a n, Historia, t. I, s. 61 . 
servi camere, „słudzy skarbu”, zależni bezpośrednio od panującego, mieli stać się extranei, „wykluczonymi”.

\section{ANEKS}

Teksty publikowanych dokumentów łacińskojęzycznych przygotowano zgodnie z zasadami wyłożonymi w instrukcji opracowanej pod kierunkiem W. Semkowicza w Polskiej Akademii Umiejętności w 1924 r. (Instrukcja wydawnicza dla średniowiecznych źródeł historycznych, Kraków 1930, s. 1-40; przedruk: J. Tandecki, K. Kopiński, Edytorstwo źródeł historycznych, Warszawa 2014, s. 311-327). Odnośnie zaś do tekstów niemieckojęzycznych wykorzystane zostały propozycje M. Thumsera, Zehn Thesen zur Editio deutschsprachiger Geschichtsquellen (14.-16. Jahrhundert), w: Editionwissenschaftliche Kolloquien 2005/2007. Methodik - Amtsbücher - Digitale Edition - Projekte, Torun 2008, s. 13-19).

Za pomoc w przygotowaniu edycji dokumentu hebrajskiego oraz jego tłumaczenie i liczne konsultacje winny jestem wdzięczność Pani dr Annie Jakimyszyn i Panu dr. hab. Maciejowi Tomalowi z Instytutu Judaistyki Uniwersytetu Jagiellońskiego.

1.

[Kraków, czerwiec 1485]

Starsi kahału krakowskiego oznajmiaja w imieniu catej gminy, iż Żydzi krakowscy nie będq odtad brali udzialu $w$ handlu detalicznym na terenie miasta $z$ wyjątkiem sprzedaży niewykupionych zastawów na ściśle określonych warunkach oraz wykonywanych wtasnoręcznie przez ubogie kobiety części garderoby - tekst hebrajski.

Or.: ANK, sygn. 658/1249; dokument papierowy o wymiarach: $218 \times 162 \mathrm{~mm}$; na odwrociu wspótczesna ręka: Littera Hebraica Judeorum.

Wyd.: F.H. Wettstein, Mi-pinkase ha-kahal be-Kraka: le-korot Yiśra'el va-hakhamav, rabanav u-manhigav be-Polania bi-khelal uve-Kraka bi-ferat, Bresloia [1901], s. I-II (z oryginatu).

Fot.: M. Bałaban, Historia Żydów w Krakowie i na Kazimierzu 1304-1868, t. I, wyd. 2, Kraków 1931, fot. po s. 114.

1 הקהל נתרצינו החתומי מטה ראשי ק"ק דקראקוב מודים ומעידים בחתימת ידינו איך שבהסכמת כל אנשי

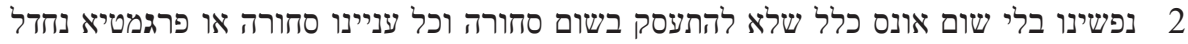

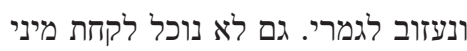

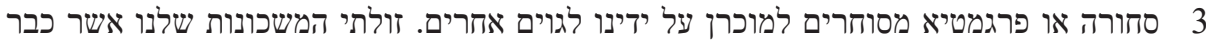

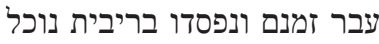

4

ברחובות ובשווקים בתוך העיר

5

מר"ק. ואותם המשכונות

6 נמכור שנוכל להשבע עליהם שבועה דאוריתא על עשרת הדברות שהם שלנו. ואם יקרה שאיש או

אשה בזדון רוחו ילך ויש להבע 
7 מטלטלים לתוך העיר למוכרם חדשים או ישנים . וימצא שימכרם או שירצהם למוכרם באזה יום שירצה שיהיה זולתי בשני העיר למכים 8

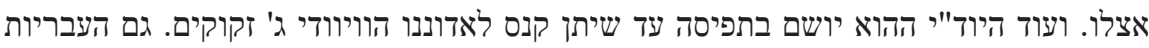

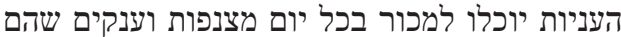
9

לעשות ולקים כל האי ומלא 10 דלעיל בלי עורמה ובלי מרמה כתבנו וחתמנו משה ב"ר אפרים זלה"ה על ובלי

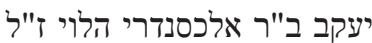

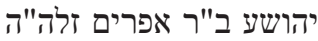
מרדכי ב"ר יעקב ז"ל הי"ד ביד

a Stowo skreślone przez skrybę.

\section{[Przektad]}

1. My niżej podpisani mężowie świętej gminy Kraków oświadczamy i ogłaszamy, podpisując się własnoręcznie, że za zgodą wszystkich mężów kahału porozumieliśmy się i zgodziliśmy się dobrowolnie 2 . bez żadnego gwałtu, że nie będziemy się trudnić żadnym handlem. Wszystkie sprawy handlu i sprzedaży anulujemy i pozostawiamy całkowicie. Nie możemy również podejmować żadnego 3. handlu i sprzedawania towarów przez nas innym gojom. Nie dotyczy to przedmiotów u nas zastawionych, które posiadamy przed długi czas i które zostały przejęte za odsetki. Możemy je 4. sprzedawać w naszych domach, kiedy tylko nadarzy się okazja. Ale owych przedmiotów nie będziemy mogli zabierać i wynosić na sprzedaż na ulice i place targowe w mieście 5. poza dwoma określonymi dniami w tygodniu, to jest w środy i piątki, które są dniami targowymi, oraz w dni jarmarku. A będą to takie przedmioty zastawione, 6 . które będziemy sprzedawać, co do których możemy złożyć przysięgę Tory na Dziesięć Przykazań, że do nas należą. A jeśli się zdarzy, że ktoś, czy to mężczyzna, czy kobieta, weźmie 7. i wyniesie do miasta na sprzedaż rzeczy nowe lub stare i okaże się, że sprzedaje je z zamiarem sprzedaży, któregoś dnia poza dwoma 8. dniami wspomnianymi wyżej; oraz w czasie dorocznego jarmarku, to rajcy mają prawo zabrać im ruchomości, które u niego się znajdują. Ponadto ów Żyd zostanie 9. zatrzymany, aż wniesie karę na rzecz naszego pana wojewody w wysokości trzech grzywien. A ubogie Żydówki będą mogły sprzedać czapki i kołnierze, które zostały 10. przez nie wykonane własnoręcznie. I oto to pismo będzie na dowód i świadectwo w rękach rajców i mieszczan, że to, co wyżej powiedziane, obowiązuje bez 11. żadnej wymówki czy wybiegu. Spisaliśmy i podpisali: Mosze syn Efraima, jego pamięć dla przyszłego świata; Jaakow syn Aleksandra Halewi, jego pamięć dla przyszłego świata; Jehoszua syn Efraima, jego pamięć dla przyszłego świata; Mordechaj syn Jaakowa, jego pamięć dla przyszłego świata. 
Ttumaczenie dyplomu starszych kahału krakowskiego na tacine

[Kraków, czerwiec 1485]

Sygn.: ANK, sygn. 658/1250; karta papierowa o wymiarach: $213 \times 320 \mathrm{~mm}$; na odwrociu współczesna ręka: Copia littere Judeorum in Latinum [sic].

Kop.: ANK, rkps $n r$ 1449, k. 56v; w kopi: Ipsum originale Haebraice scriptum extat in archivio in pixide laminea (XVII w.).

Wyd.: Kodeks dyplomatyczny miasta Krakowa, wyd. F. Piekosiński, t. I, Kraków 1879, nr 192 (z kopii).

Transsumptum littere Judeorum Hebraice scripte.

Nos seniores Judei de Cracouia inferius notati recognoscimus / et testificamur cum sigillo manus nostre proprie, qualiter unanimi / voto tocius communitatis nostre consensimus et super nos recepimus / cum bona voluntate nostra absque omni coactione non mercari neque habere aliquas merces aut res mercatorias, sed illis renunciare et eas in toto dimittere. Eciam nullas merces aut res mercatorias recipere volumus a mercatoribus ad vendendum per manus nostras aliis Christianis, solummodo pignora nostra, que iam tempora impigneracionis persteterunt et in usuris deperierunt, talia vendere possumus in domibus nostris singulis temporibus, quando evenerit. Nec talia pignera portare audeabimus ad negociandum vel vendendum in plateis aut in foris publicis in civitate vel circa civitatem, nisi in duobus diebus deputatis in septimana, videlicet feria tercia et feria sexta et in diebus nundinarum et illa pignora nos vendere debemus, super que iurare possumus ad Decem Precepta, quod nostra sunt. Et si contigerit, quod aliquis virorum vel mulierum presumptuose propria sponte deambulaverit et huiusmodi res ad vendendum deportaverit, sive sint nove sive veteres, et reperti fuerint, quod eas venderent vel vendere vellent, in quacunque die id fieret demptis prenotatis duobus diebus et nundinis, extunc incole civitatis facultatem habebunt illos vel illas recipere simul cum rebus, que apud eosdem reperte fuerint. Insuper talis Judeus vel Judea debet mitti ad carceres quousque dabit penam trium marcarum domino pallatino. Attamen Judei seu Judee pauperes poterint quolibet die vendere pepla et colloria, que sole operantur et laborant. Et hec littera erit in testimonium et documentum in manibus dominorum consulum et civium civitatis ad faciendum et confirmandum omnia superius expressa absque omni fraude et dolo. Hanc litteram scripsimus et sigillavimus nos hic infra scripti signanter: Moyses filius Effraym, Jacob filius Alexandri, Jozue filius Effraym, Mardocheus filius Jacob.

3.

[Kraków, czerwiec 1485]

Ttumaczenie dyplomu starszych kahatu krakowskiego na niemiecki

Sygn.: ANK, sygn. 658/1251; karta papierowa o wymiarach: $312 \times 218 \mathrm{~mm}$; na odwrociu wspótczesna ręka: Copia littere Judaice de verbo ad verbum ipsis interpretantibus scripta 92 in Almanico 1492.

Wyd.: F.H. Wettstein, Mi-pinkase ha-kahal be-Kraka, s. II, przyp. (z oryginatu).

Wir eldsten Juden von Crokaw undergesegelten bekennen und geczewgen mit zigel unserer hantschrifft, wy das mit eynykeit der ganczen / gemenen haben wyr 
vorwillet und haben entphangen uff uns unserem gutten willen an allen getwangk, nicht zw handeln und zw / haben mit keyner kawffmanschacz ader cremerey, dy solle wir vormeiden und lasen volkomlich. Auch sulle wyr nicht nemen kenerley koffmanschacz ader cremerey von kofflewten zw vorkauffen das durch unserer hant anderen cristen, nort unsere phande, dy do nw zynt vorstanden yr czeyt und zeyn verlorn ym wocher, dy $\mathrm{mo}^{\mathrm{e}}$ ge wir vorkauffen yn unsern hewsern yn aller czeit, wenn zich ys fuget, und dy zelbige phande solle wyr nicht torren ummb tragen zw handeln und ZW vorkauffen zy yn den gassen und uff den margkten yn der stat und czwusschen der stat north yn czwen gesaczten tagen yn der woche, das yst am dinstag und am freitagk, und auch yn tagen des jormargktis, undt dy zelbigen phande zulle wyr vorkauffen, do uff wyr mo ${ }^{\circ}$ gen eyn eid thun uff dy czehen gebot, das zy unser zeyn und worde sych ys fogen, das eyn man ader ey fraw mit frewel zeines gemuttiis worde gen und worde ummbtragen gerethe czwusschen der stad zy czw vorkoffen new ader alt und worde gefunden, das her zy vorkaufft ader wolt vorkoffen, an welchem tage das were, an dy obgenante czwen tage und ym yormargkt, des zeyn dy statlewte geweldig, zy zW nemen mit alle den gerethen, dy bey $<\mathrm{yn}>$ gefunden worden und noch mer der zelbige Jude, der zal geleget werden yn dy gefengknes, bys das gibt 3 marg busse den herrn woywoden. Dy armen Juden dy mogen vorkauffen alle tage hawben und colner, dy zy zelbes arbeten und machen. Und dyzer briff zal zeyn czw geczewgnes und beweisunge yn dy hende der herren des rothes und lewte der stat, $\mathrm{zW}$ thun und $\mathrm{zw}$ bestetigen alles das do obgenent yst, an alle hinderlist habe wyr yn geschriben und gesigelt, dy noch geschriben als nemlich: Moyses zon Effraym, Jocob zon Alexandri, Jozwe zon Effraym, Mardochey zon Jocob.

\section{4.}

Kraków, 14 czerwca 1485

Jan Amor z Tarnowa wojewoda krakowski zatwierdza podjęte przez starszych kahatu krakowskiego postanowienia względem udziału Żydów krakowskich w handlu detalicznym na terenie miasta.

Or: ANK, sygn. 658/1248; dokument papierowy o wymiarach: $212 \times 237 \mathrm{~mm}$; pod tekstem dokumentu odciśnięta przez papier na podkładzie woskowym pieczęć herbowa wystawcy; na odwrociu wspótczesna ręką: Littera Judeorum; Littera Joannis Amor palatini Cracouiensis de mercatura Judeorum hic in Cracovia de data 1485.

Kop.: ANK, rkps $n r$ 1449, k. 57r. (XVII w.).

Wyd.: Kodeks dyplomatyczny miasta Krakowa, t. I, nr 193 (z kopii).

Johannes Amor de Tharnow pallatinus Cracouiensis ${ }^{l}$ vigore presencium recognoscimus, / quomodo Judei Cracouienses dicioni et potestati nostri pallatinatus dediti et subiecti ad / nostram accedentes presenciam non nullos articulos, punctos et quasdam ordinaciones / et statuta videlicet videlicet [sic] infra scripta benivole, non coacti, civitati tenere et inviolabiliter observare compromiserunt. Primo, quia mercari non debent et omnes res mercatorias volunt et debent ommittere. Non debent neque volunt recipere a mercatoribus res aliquas mercatorias et easque vendere Christianis per manus eorundem quocumque nomine vocarentur, nisi ipsorum vadia propria, que 
ipsis invadiantur per Christianos et postea non exemuntur, sed apud ipsos manent et perduntur in usura, wlgariter vystoyą sye. Item omnia possunt vendere, super que possunt iuramenta facere et docere iuramento, quod iam essent illorum propria, et eadem possunt vendere in domibus eorum temporum occurencium [sic]. Item eadem vadia non debent portare per civitatem vendentes, nisi in duobus diebus forensibus, videlicet feria tercia et feria sexta, et in foro annuali et quicumque Judeorum seu Judearum portare vendendo per civitatem inveniretur seu arrestaretur, quod vellet vendere quascumque res sive novos sive veteres, demptis prefatis diebus forensibus et annuali foro, debent sibi recipi et Judeus sive Judea debet castigari sessione et pena domino pallatino trium marcarum. Item Judei seu Judee pauperes debent et possunt vendere pepla et colleria, que sole laborent et operantur. Ut autem premisa habeant robur perpetue firmitatis sigillum nostrum iussimus presentibus imprimendum. Datum Cracouie feria tercia infra octavas Corporis Christi anno Domini millesimo quadringentesimo octuagesimo quinto.

${ }^{1}$ Jan Amor z Tarnowa, wojewoda krakowski w latach 1479-1490 (Urzędnicy małopolscy XII-XV wieku. Spisy, Wroctaw 1990, s. 130, nr 476).

\section{BIBLIOGRAFIA}

Ameisenowa Z., Biblia hebrajska XIV-go wieku w Krakowie i jej dekoracja malarska, Kraków 1929.

Bałaban M., Przegląd literatury historii Żydów w Polsce, Kwartalnik Historyczny 17, 1903.

Bałaban M., Die Krakauer Judengemeinde-Ordnung von 1595 und ihre Nachträge, Jahrbuch der Jüdisch-Literarischen Gesellschaft 2, 1912.

Bałaban M., Felwel Hirsz Wetstein, Nowe Życie 1, 1924.

Bałaban M., Historia Żydów w Krakowie i na Kazimierzu 1304-1868, t. I, wyd. 2, Kraków 1931.

Cohn H. H., Juramentum Judaeorum, more Judaico (The Jewry Oath), w: Encyclopedia Judaica, wyd. 2, red. F. Skolnik, Detroit 2007.

Jurek T., Stanowisko dokumentu w średniowiecznej Polsce, Studia Źródłoznawcze 40, 2002.

Levitats I., Oath more Judaico w: Encyclopedia Judaica, wyd. 2, red. F. Skolnik, Detroit i in. 2007.

Müller E., Żydzi w Krakowie w drugiej połowie XIV stulecia, Kraków 1906 (Biblioteka Krakowska 35).

Niemiec D., Siedziby żydowskie w średniowiecznym Krakowie, w: Cracovia Judaeorum 3D. Katalog wystawy, Kraków 2013.

Olszowy-Schlanger J., Fragmenty rękopisów hebrajskich w Bibliotece Jagiellońskiej i ich znaczenie, w: Studia żydowskie w Polsce - przeszłość, stan obecny, perspektywy. Studium selektywne, Kraków 2014 (Prace Komisji Historii i Kultury Żydów PAU 6).

Olszowy-Schlanger J., Binding Accounts. A Leger of a Jewish Pawn Broker from 14th Century Southern France (MS Kraków, BJ Przyb/163/92), w: Books within Books. New Discoveries in Old Book Bindings, Leiden-Boston 2014.

Planer I., rec.: F. H. Wettstein, Kadmoniyot mi-pinkesa'ot Yeshanim: le-korot Yiśra'el be-Folin bi-khelal uvi-Kraka bi-ferat / Quellenschriften zur Geschichte der Juden in Polen, insbesondere in Kraków, Kwartalnik Historyczny 8, 1894.

Schipper I., Studia nad stosunkami gospodarczymi Żydów w Polsce podczas średniowiecza, Lwów 1911 (Monografie z Historii Żydów w Polsce 4).

Starzyński M., Krakowska rada miejska w średniowieczu, Kraków 2010 (Maiestas, Potestas, Communitas 3). 
Starzyński M., Średniowieczny Kazimierz, jego ustrój i kancelaria, Kraków 2015.

Starzyński M., Opis rękopisu nr 3361, w: Kalendarz domu altarystów kościoła Mariackiego w Krakowie, wyd. B. Wyrozumska [w druku].

Wettstein F.H., Devarim 'atikim: mi-pinkese ha-kahal be-Kraka le-korot Yiśra'el va-hakhamav, rabanav u-manhigav be-Polanya bi-khelal uve-Kraka bi-ferat / Materialen zur Geschichte der Juden in Polen, insbesondere in Krakau, Kraka 1892.

Wettstein F.H., Mi-pinkase ha-kahal be-Kraka: le-korot Yiśra'el va-hakhamav, rabanav u-manhigav be-Polania bi-khelal uve-Kraka bi-ferat, Bresloia 1901.

Wyrozumska B., Kancelaria miasta Krakowa w średniowieczu, Kraków 1995.

Wyrozumska B., Wyrozumski J., Nowe materiały do dziejów Żydów krakowskich w średniowieczu, w: tychże, Cracovia mediaevalis, Kraków 2010.

Wyrozumski J., Kraków do schyłku wieków średnich, Kraków 1992 (Dzieje Krakowa, t. I).

Zaremska H., Iuramentum Iudeorum - żydowska przysięga w średniowiecznej Polsce, w: E scientia et amicitia. Studia poświęcone Profesorowi Edwardowi Potkowskiemu w sześćdziesięciopięciolecie urodzin i czterdziestolecie pracy naukowej, Warszawa-Pułtusk 1999.

Zaremska H., Żydzi w średniowiecznej Polsce. Gmina krakowska, Warszawa 2011.

Zaremska H., Juden in mittelalterlichen Polen und die Krakauer Judengemeinde, Osnabrück 2013 (Klio in Polen 17).

\section{The oldest Hebrew document on Polish lands (1485) and its translation}

\section{Summary}

The object of interest for the author of this paper is the oldest (1485) surviving document written in Hebrew on Polish lands, connected with the history of the Cracow Jewish community. The elders of the qahal proclaim in it, that from that moment the Jews of Cracow will not participate in retail commerce (with Christians), except for the owners of deposits which were not purchased on time and which they will be allowed to put up for sale, but only in their own houses, except for Tuesdays and Fridays (market days) and during the fairs taking place in Cracow, when they may put them up for sale in public. Poor Jewesses are also allowed to sell coifs and necklaces produced by them. The present article discusses the possible context in which the charter was issued. The author, having studied the history of the Cracow community in the second half of the $15^{\text {th }}$ century, as well as the trade policy of large cities in the Kingdom of Poland, situated it among the activities pursued by burghers of the Crown cities, aiming at restricting the rights of guest merchants, which category was intended to include Jewish merchants. The appendix contains the edition of the charter, together with the translation into Polish, as well as its translations into Latin and German, made in 1492, and also a document of the voivode of Cracow, Jan Amor of Tarnów, dated 14 June 1485, which confirmed its rule. 